\title{
The Patterns of Democracy in Context of Historical Political Science
}

\author{
Jiacheng $\mathrm{He}^{1}$
}

Received: 18 November 2021 / Accepted: 7 December 2021 / Published online: 8 January 2022

(C) The Author(s) 2021

\begin{abstract}
The patterns of democracy are related to the success or failure of national governance; hence, they are a key topic in the theoretical research of political science. It is difficult to comprehend the worldwide political conflicts caused by the promotion of liberal democracy in the study of democratic models that have liberal democracy as their core. The emphasis of historical political science on the genes of civilization provides an opportunity to reinterpret the patterns of democracy. Relying on specific civilization genes, the patterns of democracy can be divided into the "value pattern", which is shaped by historical civilization genes, and the "practice pattern", which is based on the "value pattern". Based on Christian concepts, Western civilization produced liberal democracy as the value pattern, and the value is inherited through the practice pattern of party democracy. Chinese civilization has continued the tradition of people-orientation and consultative practice, establishing socialist democracy in value and consultative democracy in practice. Theoretically, the analytical framework of the value pattern and the practice pattern of democracy illustrates the source of the diverse patterns of democracy, which helps demonstrate the limitations of liberal democracy and points out the possibility of developing a non-liberal democracy pattern.
\end{abstract}

Keywords Civilization genes · Consultative democracy $\cdot$ Liberal democracy · Patterns of democracy $\cdot$ Socialist democracy

What are the core values advocated by modern states? Popular sovereignty is surely the overall common value of humanity. However, common value does not guarantee a common destiny for all, especially for those in developing countries. For example, India did not become like Britain by implementing the British representative democracy (parliamentary system), neither did the Philippines become like America by implementing the American representative democracy (presidency). The key to the

Jiacheng He

hejiacheng@ruc.edu.cn

1 School of International Studies, Renmin University of China, Beijing, China 
internal logic is that the democratic form chosen by these countries cannot achieve good governance naturally, and the common value of popular sovereignty is still like a castle in the air. Western democracy, which is known as "liberal democracy", could be described as a combination of two distinct vehicles that are not even traveling on the same path. "Liberalism" is a set of values rooted in a specific historical civilization and can be regarded as a value pattern that frames democratic politics. Liberalism is also the ideology of the bourgeoisie, liberal values are based on a capitalist society, and liberal democracy is capitalist democracy in nature. Democracy is a modern form of political practice, a practice pattern that reflects the value pattern. Furthermore, the quality of democracy is directly controlled by the social structure in which these values exist. Apart from the analysis of the relationship between the value pattern and the practice pattern, to understand liberal democracy, it is necessary to interpret the social structure where the value pattern exists or which it represents. For the purpose of analytical operability, social structure is placed within the value pattern in this paper, because values are the concentrated expression of social relations. In this way, the relationship between the value pattern, practice pattern, and social structure of democracy is reduced to the relationship between the value pattern and the practice pattern. By the same logic, "socialist democracy" also needs to deal with the relationship between socialism, which is a political value, and democracy, which is a political practice.

The "value pattern" and the "practice pattern" of democracy should possess some inherent unity or continuity. Any tensions or conflicts between the two will inevitably lead to the deviation of democratic politics from its ideals, and result in the destruction of democracy itself. This is the internal mechanism of the dilemma of liberal democracy. Not only will history not end in liberal democracy, but it also has trouble getting out of the dilemma of invalid governance within a short period of time. Where is the democratization of the developing world heading? How do western countries address the challenges confronting liberal democracy? These issues, which are pertinent to the fate of many countries, are bound to be the focus of political science research. Finding existing research on democratic models to be insufficient, this paper attempts to expound the plight of Western democracy and the developing Chinese democracy within the analytical framework of the value pattern and practice pattern of democracy.

\section{Research on the Patterns of Democracy: Problems and Breakthroughs}

Democracy concerns political order. Hence, there are so many concepts and theories about democracy that have a major impact on social science research and political practice. Liberal democracy is one that cannot be ignored. The theory of liberal democracy has a long history. After World War II, thanks to the efforts of scholars like Joseph Schumpeter, Seymour Martin Lipset, Robert Dahl, and Giovanni Sartori, after the continuous transformation of the concepts of democracy and legitimacy, the theory of liberal democracy became a defensive theory and finally gained dominance in the global democratic discourse (Yang 2016a, b; He 2020). Due to its huge 
influence in theory and reality, liberal democracy became the center of research on the patterns of democracy. Research regarding this includes David Held's Models of Democracy (Held 1998), Arend Lijphart's Patterns of Democracy: Government Forms and Performance in Thirty-Six Countries (Lijphart 2006), and Sartori's The Theory of Democracy Revisited (Sartori 2009).

Held mainly describes the characteristics of models of democracy in the West in different periods and their interrelationships. His book focuses on expounding representative democratic ideas and concepts-classical democracy, republican democracy, and liberal democracy, although it fails to clarify the relationship between the models of democracy in theory and the forms of democracy in practice. Lijphart distinguishes the Westminster model of democracy from the consensus model of democracy, but still regards majority rule as the minimum of democracy. That is recognition of the priority of liberal democracy, only that consensus democracy is required to improve its performance. The two scholars' discussions on the patterns of democracy are limited to the framework of Western liberal democracy. They do not explain why and how liberal democracy came into being in the West. More importantly, studies on the patterns of democracy that revolve around liberal democracy, often consider the latter as the "end of history". They fail to explain the political conflicts that have arisen worldwide due to the promotion of liberal democracy. In this regard, Sartori's research may be insightful. Sartori focuses on the relationship between freedom and democracy and demonstrates the liberal origin of "electoral democracy", i.e., partisan democracy. He argues that democracy should be framed within liberalism, or that liberalism is the anchor of democracy. According to Sartori, democracy is "a name for a civilization" or "for the political end product of Western civilization" (Sartori 2009, p. 15). The chaos of democracy in world politics may be rooted in the fact that "competitive elections", as a form of political practice, are separated from the cultural soil that produces this form of democracy, resulting in the conflict between the political practice and the respective historical civilization gene.

In The Theory of Democracy Revisited, Sartori helps us understand the patterns of democracy by illustrating the importance of the historical civilization gene of democratic practice, or the inherent unity of political practice and political value. Philippe Schmitter holds the same position, arguing that the failure of democratic transformation in many countries is due to their "genes" (Schmitter 2012, pp. 106107). This is undoubtedly a research approach to factual historical political science. Historical political science is the study of the historical origin and historical causality of major political issues. Its emphasis on civilization genes provides an opportunity to reinterpret the patterns of democracy. The "history" in historical political science is not only an idea and imaginative concept, but also an ontological existence. We need to study the "existence" and its direct correlation between the past and the present, based on which we can propose explanatory concepts or theories to understand the relationship between civilization genes and current political practice. Therefore, historical political science emphasizes the differences between civilizations. The historical civilization genes of one country may be strong or weak, but almost all countries must have appropriate political values, political systems, and corresponding behavior (Yang 2019b). In different living environments, people have 
created different regional civilizations, which include both spiritual and material elements. Political studies should pay attention to the influence of civilization on political ideas, systems, and behavior.

To understand the relationship between civilization genes and politics, one should pay attention to temporality and context. Historical political science represents an academic tradition where the focus is on how time and context play a role in the origin and evolution of ideas, systems, and behavior that affect political, economic, and social relations (Shi 2019). Therefore, at the macro level, historical political science mainly deals with the influence of time and context on the relationship between civilization genes and politics. Time represents vertical evolution, and context represents structural constraint. On the one hand, time has different effects on ideas, systems, and behavior, because these have a different stability classification and distinct levels. Specifically, ideas are more stable and original than systems and behavior. Therefore, the evolution of ideas in history are often relatively slow. On the other hand, the civilization genes in a specific context constrain ideas, systems, and behavior, and they match with one another. Different contexts have different historical timelines, resulting in different historical trajectories. This means that there may be tensions between institutional forms and civilization genes, and there may be contextual mismatches between the original social structure and the secondary type of government.

Although democratic politics is modern politics, it does not mean a separation from tradition. Tradition and modernity are not binary oppositions. Modernity is a natural continuation of tradition. "Popular sovereignty" is an overall and common modern value, but people must first rely on established cultural traditions or civilization genes to achieve this overall democratic value. We can follow the route of historical political science to divide the patterns of democracy into different dimensions and levels, namely, the temporal or historical "value pattern" and the contextual or realistic "practice pattern" of democracy. When the historical and realistic factors of democracy are linked together, the "public good" of "popular sovereignty" becomes concrete. The pattern of democracy based on a particular civilization gene is the "value pattern" of democracy, and the "value pattern" is the national or cultural pattern, which guarantees the implementation of popular sovereignty. Since there are multiple cultures, there will be multiple "value patterns" (Yang 2018, p. 447). According to the idea of "multiple modernities" proposed by S. N. Eisenstadt, although the Western model of modernity enjoys some priority in history and will continue to serve as a basic reference for other modernities, modernity is not equal to Westernization. The Western model of modernity is not the only "real" modernity (Eisenstadt 2006, p. 38). The same is also true for the value pattern of democracy. As a historical continuity, political practice is bound to continue the historical political value, which means that the practice pattern of democracy needs to match its value pattern. Otherwise it will lead to "democratic conflicts"- tensions between the practice pattern and the value pattern and the resulting political conflicts.

To sum up, the research on the patterns of democracy from the perspective of historical political science can be summarized as the influence of temporality and contextuality on the value pattern and the practice pattern of democracy based on specific civilization genes. In other words, temporality shapes the value pattern, 
and contextuality shapes the practice pattern. As contextuality originates from the axis of time, the practice pattern is therefore endogenous to the value pattern, and the practice pattern that conflicts with the value pattern is likely to lead to "invalid democracy". Therefore, the patterns of democracy in the perspective of historical political science consists of the value pattern and the practice pattern. Liberal democracy includes liberalism as the value pattern and electoral democracy as the practice pattern, and the value pattern is implemented through the practice pattern. On this basis, we can explain the civilization origin of liberal democracy and global political conflicts, which are caused by the mismatch between the value pattern and the practice pattern of democracy through the promotion of liberal democracy. It is the unique accumulation of Western civilization behind liberal democracy that has led to its invalidity all over the world. In fact, the democratic values and practices outside the Western world have emerged from their respective civilizations. "Although in different societies, the development models of democratic systems are different, they are partly strongly influenced by the cultural traditions and historical experience of these societies" (Eisenstadt 2006, pp. 103-104). In the case of China, the contemporary deliberative democratic system influenced by traditional peoplebased thinking and deliberation practice is also under development.

Systems carry ideas, and history accumulates culture. Not only should the study of democratic history deal with the internal differences of different cultural contexts, but it should also investigate the history of ideas and civilizations behind the history of systems. Liberal democracy "is not just a specific political system arrangement. It is deeply inscribed in the history, culture, society, economy, philosophy and even religion of the West, and is inseparable from these factors. The question then arises: If democracy is closely connected with the history, culture, society, economy and religion of the West, how can we expect to develop Western-style democracy in non-Western countries with different histories and traditions... Democracy is not an export commodity; it cannot be transplanted from one piece of cultural soil to another piece of cultural soil like a rose. It needs careful care and adjustment in line with local conditions" (Wiarda 2004, p. 7). The study of the patterns of democracy centered on liberal democracy examines and evaluates the democratic situation in China and other regions from a specific perspective. It ignores the fundamental influence of other civilizations, which is parallel with Western civilization, on the democratic practices within their respective spheres of influence. The emphasis of historical political science on the ontological significance of civilization provides a basis for rethinking the patterns of democracy. This paper explains how Western civilization and Chinese civilization derive their own value patterns and practice patterns of democracy.

\section{Western Civilization: Liberalism and Party Democracy}

After World War II, Western political discourse, which was shrouded by "modernization" and "democratization", defended the legitimacy of the country's political system and drove the transition of other countries' political systems. Unlike the dominant paradigm that focuses on the circumstantial structure, some scholars with 
a sense of history and attempting to reveal the procedural structure, linked the source of Western liberal democracy with the development of capitalism and the building of a nation-state (Moore 2012; Rueschemeyer et al. 2016; Collier 1999; Tilly 2008).

At present, in response to the de-historicity of the mainstream democratization research, Western scholars are trying to "recover history" on two levels: one, by paying attention to the non-synchronization of the critical moments where the elements of the democratic system are produced, and their evolution, and how they portray the multiple conflicts and motivations that affect political actors (Ziblatt 2006; Capoccia and Ziblatt 2010); and two, by pushing back the perspective of democratization research from, after World War II, to the nineteenth century, the early modern period, and the Middle Ages, and collecting historical data on various stages of democratization (Knutsen et al. 2016).

However, both, the inspiring historical sociological research and the emerging historical turn may only reveal the tip of the patterns of democracy. First, the Western experience of social structural changes highlights the uniqueness of the Western path, and it cannot be used to explain the legitimacy of the political patterns formed by the non-Western world based on its own historical and cultural conditions. Second, the depiction of the historical characteristics of the democratic system is still centered on liberal democracy. It only shifts the focus from the operation and promotion of the system to the occurrence and its evolution, outlining the historical trajectory for liberal democracy, but it does not properly explain the liberal nature of the Western pattern of democracy. The foundation of liberal democracy lies in its unique civilization genes. The emphasis on the ontological significance of history in the research approach of historical political science provides a new guidepost for insight into the essence and origin of liberal democracy.

\subsection{Continuation or Reshaping: A Brief Overview of the Relationship between Ancient and Modern Western Democracy}

In the writings about the history of Western democracy and the history of Western democratic thought, ancient Greece is often regarded as the source of democracy. Due to its relatively sound systems, Athens became a model of ancient Greek democracy, exerting a significant impact on later generations. It is widely recognized in the Western academic circle that between 508 and 507 BCE, Cleisthenes's reform established the democracy of Athens, so 1992-1993 marked the 2500th anniversary of the birth of democracy (Dunn 2011). In the early 1990s, at the 2500th anniversary of the birth of democratic politics and the critical point of liberal democracy "ending history," Western scholars held a series of commemorative discussions, exhibitions and other activities on Athenian democracy. These reflected and strengthened the firm belief of the West that the Western democratic political tradition that originated in ancient Greece will surely win the ultimate victory all over the world (Huang 2002). It is undeniable that there is indeed a certain degree of historical continuity between ancient and modern democracy in the West. This continuity is mainly reflected in the lasting attention to the rule of the majority, the way in which it is realized, and the political ideas and political systems centered around it. However, 
the long history of democracy does not mean that it has been moving forward. On the contrary, it suggests a possibility of changes in its connotation. In different historical contexts, considerations over the same topic would not yield the same answer, which result in a major divergence between ancient and modern democracy in terms of conceptual inclination and institutional practice, although "democracy has been discussed off and on for about twenty-five-hundred years, enough time to provide a tidy set of ideas about democracy on which everyone, or nearly everyone, could agree. ... Ironically, the very fact that democracy has such a lengthy history has actually contributed to confusion and disagreement, for 'democracy' has meant different things to different people at different times and places" (Dahl and Shapiro 2020, p. 2).

In fact, ancient Western democracy and its modern counterpart are different in their goals and values. The center of ancient democracy lies in the city-state, which is an internally equal political community. The citizens themselves are the city-state. Athenian democracy had no distinction between "state" and "society", and there was no civil society, separation of power and individual freedom in the modern sense (Rowe et al. 2016, pp. 27-28). If you wanted to discover "freedom" and "individual rights" in the political system of a city-state as understood by today's mainstream political theories in the West, it was tantamount to seeking fish from a tree (Cartledge 2016, p. 127; Held 1998, p.18). The difference in the pursuit of values between Athenian democracy and liberal democracy can be found through comparison of laws. The American legal system operates within the value framework of modern liberalism, and its core principles consider that the individual precedes the state, and that individual freedom is protected from public interference. The law of Athens, or democracy in a broad sense, is not aimed at the abuse of power by the state or the majority, but at powerful individuals, and its core concern is to maintain the well-being of the community (Wallace 2006, pp. 419-421; Wang 2007b).

In terms of institutions, the difference between the value patterns of ancient democracy and modern democracy is manifested in the practice patterns. The former practices assembly democracy and the latter, representative democracy. Athens' assembly was open to every citizen and had the final decision on public affairs, such as war and peace, treaties, finances, justice, and public works (Finley 2016b, pp. 15-16). The vast majority of public offices in Athens were created by lottery, and only a few positions that required specialized skills were elected. By contrast, in modern representative democracy, representatives elected by the people under the organization of political parties are responsible for governance and decision-making. Since modern Western democracy is based on a multi-party system in the context of parliament, some believe that there was also party politics in Athenian democracy. This is a completely wrong view of the political life in Athens (Ober 1989, p. 9). The assembly democracy in Athens was not helpful for the formation of political parties. There was no political party in the modern sense, or any support groups of citizens behind political leaders (Hansen 2014, p. 495; Finley 2016a, p. 81).

In view of the changes in the patterns of democracy and its characteristics, Dahl attributes the origin of modern democracy to two transitions: the first one is the transition to city-state and the second is to nation-state (Dahl 2006). This is in fact an explanation of the evolution of Western democracy by distinguishing and comparing 
ancient and modern democracy. But Dahl does not specifically explain why and how such transitions occurred. History has defined the realm of questions for research on the fluidity of democracy and the answers are hidden within it. While searching for answers, the first thing we need to figure out is where the foundation of liberal democracy, i.e., liberalism, comes from.

\subsection{The Value Dimension of Liberal Democracy: From Western Civilization to Liberalism}

From the perspective of the history of civilizations, although Western civilization has adopted and transformed some elements of classical civilization, it is not a direct inheritance and continuation of the latter, but a new one formed in the Middle Ages (Bennett 2007, p. 7; Tierney and Painter 2011, p. 2; Berman 2008, pp. 2-3). According to Samuel Huntington, Western civilization emerged in the eighth and ninth centuries and had eight major characteristics: classical heritage, Catholicism and Protestantism, European languages, separation of spiritual authority and secular authority, the rule of law, social pluralism, representative institutions, and individualism (Huntington 2010, pp. 49-51). After analyzing these characteristics and the relationship between them, one can easily find that as a key element in Western civilization, Christianity had a significant impact on its birth and development. As Huntington says: "Western Christianity-first Catholicism and then Catholicism and Protestantism, is historically the single most important characteristic of Western civilization" (Huntington 2010, p. 49). Historians also agree. "Western Christianity was and remains the main constituent element in European thought...Throughout the history of the West, Christianity has been at the heart of the civilization it inspires...A European, even if he is an atheist, is still the prisoner of an ethic and a mentality which are deeply rooted in the Christian tradition" (Braudel 2017, pp. 350-351).

In terms of basic concepts, the contribution of Christianity to Western civilization lies in its unique theories of human nature and dualism. Regarding the theory of human nature, "... if there had been no fall, then the entire historical fabric of Christianity, the story of the first sin and the reason for an atonement, upon which the current teaching based Christian emotion and morality, collapsed like a house of cards" (Wells 1982, p. 1059). On the one hand, God's judgment and salvation will fall to the individual equally, and the homogenous starting point of human nature means a universal concept of moral equality, which eliminates inequalities caused by family, class, race, and other factors. "Christianity, coming after all this progress in thought and institutions, presented to the adoration of all men a single God, a universal God, a God who belonged to all, who had no chosen people, and who made no distinction in races, families, or states" (Coulanges 2005, p. 362). On the other hand, the pursuit of atonement and the gospel stimulates personal free will and initiative, and every believer can shed the yoke of original sin in his connection with God. Politically, the Christian theory of human nature is manifested as a preference for limited government and the rule of law. Since human nature is unreliable, those who hold public power are unreliable too. Therefore, it is necessary to guard against the government 
and restrict power. "Generally speaking, there are two ways to solve power problems in history. One is that power holders are expected to cultivate their internal morality and purify power with a perfect personality. The other is to take precautions institutionally...Considering the Christian theory of human nature, the first approach will hardly be adopted, so the second approach will be the only one available" (Zhang 2010, p. 25). Therefore, the Christian theory of human nature has nourished the rule of law tradition of Western civilization, and it is an important principle in Western political life that the state should rule within the legal framework.

Apart from the theory of human nature, Christianity's nurturing of Western civilization also stems from its dualism. According to the Christian belief, humans have the duality of the soul and the body, which generates the duality of human life, that is, spiritual life and material life. The Christian theory of political dualism, which stems from the duality of humans, classifies social organization into churches and states and social power into religious power and kingship. A classic quote about that is what Jesus says in the Bible: "Give back to Caesar what is Caesar's and to God what is God's." Christians must obey both secular authority and the authority of God. "As a new mode of thinking, the dualistic political view has defined a new political philosophy theme, a new political theory axis, and a new set of political vocabulary that are completely different from the Christian political philosophy in the classical era" (Cong 2003, p. 4). After the Pope's Revolution, the distinction between the spiritual realm and the secular realm in Christianity became clear and practical, and the development of canon law fixed dualism in various institutions. Although the Christian world underwent religious reforms in the late Middle Ages, the foundation of the dualistic political view remained intact. Reformers split Christianity into different denominations, but they never abandoned the ancient social view based on the dual structure of the church and the state. Both Lutheranism and Calvinism believed that the church is a group different from the state, the defender of all the important spiritual interests of man, and the supreme embodiment of moral authority (Watkins 2016, pp. 46-48). Christian dualism gave birth to the boundaries between individual rights and state power, and the constraints of society on the state. The change of religion separating from government is essential, and it reverses the traditional homogenous view of society and replaces it with an opposing socio-political system. Such a clear distinction between "society" and "state" and the granting of moral authority to social organizations mean that while having liberated itself from religious norms, politics suffers more restrictions. The emergence of this idea marks the establishment of Western civilization (Watkins 2016, pp. 40-41; Coulanges 2005, p. 363).

The encounter between the Christian theories of human nature and dualism and the medieval fragmented power network has produced the representative system based on pluralism and antagonistic power relations. After the Roman Empire, Europe was filled with "city-states", and even when the Westphalian system, which marked the birth of nation-states, was formed, there were nearly 2000 independent feudal lords in Germany and Italy alone. "War made states". Continuous wars made kingship, which represents national sovereignty, but the feudal lords were not completely wiped out. They remained an independent political force to restrain the king. The check-and-balance body was the parliament and its right was demonstrated as 
"no representation, no taxation." The king needed military expenses to start wars, and military expenses came from the parliament controlled by the feudal lords. Therefore, the representative system, which is the institutional arrangement of European civilization, is designed to balance antagonistic pluralism. Aside from the opposition between religious power and kingship, medieval Europe also had oppositional power relations in the secular world. Within the secular power, "Kingship in the medieval West was always characterized, in varying degrees, by a tension between monarchial power and lordship, between centralized and local authority... in which a resolution between competing claims to authority was sought...by invoking some kind of mutuality, an agreement between two legitimate forces conceived in contractual or, eventually, constitutional terms" (Wood 2019a, p. 157). The competitive distribution of political authority and economic resources by multiple social subjects finally gave birth to the feudal contractual representative system of checks and balances in the Middle Ages. This historical process highlights the inherent antagonistic pluralism in Western civilization.

In modern times, after experiencing the wave of secularization and the bourgeois revolution, Western civilization formed in the Middle Ages with Christianity, pluralism, and the representative system as its core, and gradually entered the phase of liberalism, which sees individualism as its ontology. In other words, liberalism based on individualism became the core of Western civilization. Liberalism emphasizes individualism and egalitarianism, puts individual rights above state power, and advocates multiple competitions and limited government to protect individual freedom. Almost all these values are greatly influenced by Western civilization formed in the Middle Ages. As Sartori puts it, "a nameless liberalism has constituted between the seventeenth and the twentieth centuries the most fundamental drive of Western civilization" (Sartori 2009, p. 407). The very fact that individual freedom and social diversity are fully recognized by the "liberal" civilization has enabled democracy to transform and regain its brilliance in the West.

\subsection{The Practice Dimension of Liberal Democracy: From Parliamentary Representation to Party Rivalry}

The general feature of medieval Europe is the so-called "antagonistic pluralism", that is, the fragmentation of state power. Feudal lords and other autonomous units shared many functions that should have been performed by the state (Wood 2019b, p. 10). The medieval rule was a mess, and that reflected the economic and social divisions based on small regions. People did not always know that they belonged to one of so many lords, churches, towns, princes and dukes, and kings. There were fierce competitions for jurisdictions (Goff 2011, pp. 96-97; McClelland 2014, p. 289). This fragmented state began with the collapse of the Western Roman Empire caused by the barbarian invasion. The Germanic countries that replaced the Western Roman Empire were small and their rulers were relatively weak. The two key elements drove the establishment of a consent-based representative system and hindered the development of a centralized bureaucracy (Stasavage 2016). 
According to John Keane, the oldest parliament was born in northern Spain on the Iberian Peninsula at the end of the twelfth century, when the war pressured King Alfonso IX of Leon to win the support of various forces. In the end, with the support of the nobility and the church, Alfonso IX gained the soldiers and funds provided by the township on the condition of providing protection. During the process, the nobles, the bishops, and the townspeople formed a noble triangle, producing the modern parliamentary representative system (Keane 2016, pp.146-150). Since then, this kind of representative body spread to other parts of Europe and became an important part of the political system of various places by the end of the Middle Ages. However, the Middle Ages had not yet produced universal political rights, and the election of parliamentarians was not open to all members of a society. "Consent" or "freedom" was exclusive to a few aristocrats and the propertied class. As Dahl puts it, "representative government originated not as a democratic practice but as a device by which non-democratic governments - monarchs, mainly - could lay their hands on precious revenues and other resources they wanted, particularly for fighting wars" (Dahl and Shapiro, 2020, p. 87). The prototype of the representative system in the Middle Ages played a role in the balance of power, which was mainly reflected in the fight and compromise between the king and various local public authorities. Therefore, what the medieval representative system dealt with was "not a question of peasants liberating themselves from the political domination of their overlords but lords themselves asserting their independent powers against the claims of monarchy" (Wood 2007, p. 201).

The parliamentary tradition implies the recognition of social pluralism, which believes that the state and society are not a unity. The diversity of society produces the diversity of interests and all groups need to have their own representatives in front of the state. Although there are different paths of national construction in the Western world, if we analyze it from a macro historical perspective, the representative system produced by Western civilization and its constraint on power may be unique.

The state vs. society model in the Middle Ages continues to exist in modern times, but society itself has generated an increasing number of heterogeneous interest groups. The development of capitalism and the industrial revolution in the West boosted the emergence of the bourgeoisie and the proletariat, adding class antagonism to the diversity of society. Although the bourgeoisie buried the feudal system and replaced the feudal aristocracy with the new ruling group, the traditional model of restricting the power of the monarch and government through parliament was retained. The free element that safeguarded the feudal lords' right to rule has now become the guardian of the bourgeoisie. The growth of the proletariat's strength and the socialist movements led by it has continuously called on the bourgeoisie to open up political rights and expand the right to vote. The existence of Western parliaments means that these institutions could be democratized when the pressure to expand suffrage in the nineteenth and twentieth centuries increased (Møller 2015).

Representative system is designed to accommodate social pluralism, but its "democratization" will face difficulties. As to how to balance the relationship between the "nobility" of representation and the "affinity to the people" of democracy, representative government ultimately addresses the problem by 
means of party democracy. A party is a political organization that emphasizes differences and antagonism, and its formation and development reflect the changes of social contradictions. With the expansion of voting rights, more and more heterogeneous interest groups are absorbed into the system of institutionalized competition and confrontation through political parties (Lipset 2011, pp. 123-195). In the era of representative party democracy, the conflicts of interests between different groups are mainly manifested politically as competition between parties. In practice, the party system of Western countries has made extraordinary achievements in taming democracy, and even won the loyalty of the proletariat to the capitalist democracy. At the beginning of the rise of democratic citizenship, its basic function was to mitigate the intensity of possible class conflicts, and control or ease the conflicts of class interests, so as to protect the existing property system and market system from strong impact (Macpherson 2018, pp. 61-63).

Based on Western political experience, Western democratic theorists defensively constructed the concept of democracy. After World War II, Western democracy with election and party competition as its basic form gradually became popular around the world. Joseph Schumpeter took the initiative in "restating" democracy: "Suppose we reverse the roles of these two elements and make the deciding of issues by the electorate secondary to the election of the men who are to do the deciding. To put it differently, we now take the view that the role of the people is to produce a government, or else an intermediate body which in turn will produce a national executive or government. And we define: the democratic method is that institutional arrangement for arriving at political decisions in which individuals acquire the power to decide by means of a competitive struggle for the people's vote" (Schumpeter 1999, pp. 395-396). Since then, electoral democracy has become the dominant form of democracy. According to Dahl: "Today we have come to assume that democracy must guarantee every adult citizen the right to vote" (Dahl and Shapiro, 2020, p. 3). In the practical operation of Western politics, political parties are an important tool to organize elections. The competition between the parties is an important manifestation of social pluralism in Western countries and so its practice pattern of democracy can be called party democracy.

To sum up, liberal democracy is the political expression and institutionalized reproduction of Western civilization, or the liberal democracy (with party democracy as its core) is a historical continuum of Western civilization. If party democracy ever worked well, it was because of its compatibility with the value pattern. However, the invariable practice pattern faces the changed Western civilization, i.e., the ethnic heterogeneity. Although Western civilization includes social pluralism, it is essentially only about a homogenous culture with multiple interests within the same religion and race. When homogenous culture evolves into heterogeneous culture, party democracy intensifies political division and stimulates the formation of identity politics. To put it differently, the practice pattern and the value pattern of Western democracy have produced serious internal tension, which is the underlying problem with Western democracy. In recent decades, when the party democracy as a practice pattern has declined and caused political crisis, new forms of democracy appeared and tried to remedy its defects, 
and consultative democracy is one of them. In the Western context, consultative democracy is an auxiliary institutional arrangement for party democracy. From the perspective of civilization genes, the consultation tradition of Chinese civilization based on people-orientation is more obvious and lasting. It affects the current construction of socialist democracy with Chinese characteristics.

\section{Chinese Civilization: People-orientation and Consultative Democracy}

The value pattern of liberal democracy and the practice pattern of party democracy not only profoundly influenced and even determined people's understanding of polity after World War II, but also promoted democratization across the world. China's polity is often seen as authoritarian or even autocratic because it does not meet the "standards" of the Western pattern of democracy. After the emergence of the theory of Western consultative democracy, some scholars changed their views on Chinese democracy. They believed that China's public consultation has some characteristics of consultative democracy. But many scholars still believe that there is no such thing as consultative democracy in an authoritarian regime and that consultative democracy can only develop after electoral democracy is established. Both approaches attempt to digest the new empirical world with existing theories (He 2013). To some extent, the theories of liberal democracy and deliberative democracy avoid the exploration of China's consultative political practice and its cultural and historical bases, which restricts the explanatory power of democratic theory and the imagination of democratic practice.

In the opinion of historical political science, history in the sense of ontology is crucial for the generation and revision of social science concepts and theories, which will face great tests when they depart from their contextual basis. Western consultative democracy mainly aims to correct the defect that representative democracy excludes citizen participation and tends to embrace elite politics, and make up for the deficiency of the decline of representative democracy. Therefore, it is a supplementary institutional arrangement to representative democracy (Chen 2016). The development of consultative democracy in China is completely different. Its "connection with China lies in logic as well as in history". (Zhang 2015 , p. 71). However, China's traditional society is often labeled as "despotism" and "authoritarianism" by the existing discourse system and excluded from the scope of consultation practice.

The blind spot of theory is the starting point of research. "Consultative democracy is a unique form of Chinese socialist democracy. It springs from our nation's long-established inclusive political culture, including such notions that all under heaven belongs to the people, mutual learning and inclusiveness, and seeking common ground while putting aside differences. It springs from China's political evolution in modern times, from the long-term practical experience as the CPC led the people through the course of revolution, development, and reform; from the great innovations made in our political institutions after the founding of the PRC by all political parties, people's organizations, ethnic groups, and 
people from all social strata and different backgrounds; and from the continuous innovations in China's political system since the adoption of reform and opening up. It has firm cultural, theoretical, practical, and institutional foundations" (Xi 2017, pp. 293-294). Preliminary results of research into the origin of consultative democracy in China, which is a major issue in historical political science, have been achieved (Lin 2003). This part mainly deals with the civilization foundation and practice development of consultative democracy in China, and is based on the findings about Chinese cultural tradition and its evolution, rather than the hindsight of "China following the West, and ancient corresponding to modern". On the one hand, China and foreign countries, each has their own evolution logic in consultative democracy. Hence, research on China's consultative democracy should not follow the Western theory of consultative democracy as a standard. On the other hand, the emphasis on the resources of local consultative tradition does not mean that ancient and modern consultative elements should be discriminated correspondingly. There is a need to outline the endogenous inheritance and transition path of consultative politics at the macro level. Therefore, based on acknowledging the rich practices of consultative democracy in contemporary China, we can only respond to the criticism from the theory of liberal democracy and renew the understanding of China's consultative democracy by identifying its local origin.

\subsection{Historical Continuity: The Basis for Understanding China's Consultative Political Tradition}

Compared with the "relay-style" evolution of Western civilization, the important feature of Chinese civilization is its historical continuity. John King Fairbank comments on it by comparing China and the West, arguing that "in spite of the immensity and variety of the Chinese scene, we need not be surprised that this subcontinent has remained a single political unit where Europe has not; for it is held together by a way of life even more deeply rooted than our own, and stretching even farther back uninterruptedly into the past." (Fairbank 1999, p. 8).

How to explain the historical continuity of Chinese civilization that has lasted 5000 years? The theory of the China stratum put forward by Professor Mizoguchi Yuzo, a famous Japanese historian and an expert on China's history, is very inspirational. According to Mizoguchi, "on the one hand, Chinese civilization has been deformed due to a long period of ethnic conflicts and convergence in history. On the other hand, the main Chinese culture has been developing continuously, driven by the dialectical movement of the internal contradictions of the China stratum" (Mizoguchi 1996, p. 37). This internal movement gives China "its own historical reality and development, which is reflected in the slow and continuous changes of various phenomena in different ages. Therefore, modern China should be understood from the relationship between contemporary, modern, and pre-modern times" (Mizoguchi 2011, p. 111). The elements, namely "genes", supporting the continuous changes of Chinese civilization include-unchanged language, script, and Chinese nationhood; the idea of national unity and the people-oriented thought of state governance; 
the administrative prefecture-county system, bureaucracy, and meritocracy; cultural inclusiveness and the golden mean; freedom and autonomy of social life, and family ethics. These "genes" are internalized in the blood of the Chinese nation inhabiting in a fixed territory, forming a community of Chinese civilization lasting for thousands of years. Therefore, China can be called the "community of Chinese civilization genes", that is, a community composed of civilization genes (Yang 2016b). Civilization genes pull the historical process to create the internal driving force for the development of the agricultural society in ancient China. Independent farmers with small landholding provide power and wealth for social development, endogenous government capacity provides institutional guarantee for social development, and effective state governance provides adjustment mechanism for social development. As a result, China can continue to stay in a stable national territory for a long time and form a unified and stable political community (Xu 2016).

The great changes caused by external shocks in modern times did not interrupt the historical continuity of China. External factors have played a part in the new form after being selected, transformed, and absorbed by the community of Chinese civilization genes. Our current national governance system has been developed and gradually improved over a long period of time on the basis of our historied heritage, cultural traditions, and social and economic development (Xi 2014, p. 105). The same is true of the consultative "governance of China", which embodies an inheritance of the values of Chinese civilization genes and a renewal of the form of national governance system. Within the analytical framework of the value pattern and the practice pattern of democracy, the core value of contemporary Chinese consultative democracy is ancient people-orientation and modern socialism. The practice pattern has evolved from administration-led consultative institutional arrangement to the CPC-led consultative democracy system.

\subsection{The Value Dimension of Consultative Democracy: From People-orientation to Socialism}

In the tradition of Chinese political thought, the people-oriented thought occupies a very important position and is "the mainstream of Chinese political thought" (Jin 2008 , p. 5). It treats people as the main object of political thinking, explores the governing rules and ways of administration through comprehensive investigation of various virtual or real political relations between Heaven (Dao) and the people, the state (Tian Xia) and the people, the monarch and the people, and the officials and the people. It establishes a systematic political theory revolving around the core idea of "people-orientation", which, in a sense, can be used as a generic term of the political thinking in ancient China (Zhang 2007). Therefore, "by integrating other important ideas in ancient political thought, the people-oriented idea or thought can best demonstrate the characteristics of ancient Chinese political thought" (Liang 2020, p. 138).

The people-oriented thought in China originated from its leaders' or monarchs' governance responsibilities for the people and their concerns about people's livelihood when the state came into being. Therefore, the people-oriented thought is not 
only the source of the kingship, but also a congenital restriction on it. "People-orientation" has become the "meta-problem" in the traditional Chinese political theory (Ning 2019). The people-oriented thought is not only a theory concerning the legitimacy of political power, but also a natural pursuit of governance. When tracing the origin of the people-oriented thought, it is difficult to determine which thinker first came up with it at a certain point. But relevant discussions existed as early as in the three ancient dynasties of Xia, Shang, and Zhou. One can also find some classical descriptions in Shang Shu, such as "The people are the foundation of the state, and the state is peaceful when the foundation is solid"; "Heaven loves the people, and Heaven will allow what the people want"; "Heaven hears and observes from the people to know the good and evil of men; Heaven listens to the opinions of the people to grant a reward or impose a punishment"; and "The voice of the people is the voice of God". Generally, the views of God and Heaven constitute the philosophical foundation of the people-oriented thought, and the original source from which people-orientation becomes an idea. By transforming the invisible Heaven into the tangible people, the people-oriented thought has completed the critical transition from the politics of Providence to that of public opinion (Lin 2017).

The people-oriented thought was formed in the Spring and Autumn Period and the Warring States Period. During that time, the importance of royal families declined, and the feudal princes competed with one another. Thinkers noted how the political turmoil had highlighted the importance of public sentiment. The agitation of the times offered realistic materials for the development of political thoughts and provided ideological space for the creation of intellectual elites. As a matter of fact, the people-oriented thought is a resource shared by the various schools of the pre-Qin period. The theoretical differences among the schools are not so much the existence of the people-oriented thought as the way of thinking and the combination and ordering of the elements of the thought based on political preference and effectiveness evaluation. Therefore, the "people-oriented" thought is a consensus reached by and a proposition for all schools (Liang 2020, pp. 150-151). Among the schools, Confucianism has played an important role in the elaboration and publicity of the people-oriented thought, which has attracted the most attention of later generations. Confucius, Mencius, and Xunzi all made important discussions on the idea of people-orientation. Confucius emphasized "benevolence", saying that "the benevolent loves others". He advocated the integration of politics and morality, arguing that the ruler should "save money and love the people, and use the resources of the people at the right time of the year" and "cultivate himself to benefit others and all the people." Based on Confucius' ideas, Mencius went further to develop the idea of "benevolent government". He stated that "the people are the most important, the state comes next, and the monarch is the least important." Mencius established "the great foundation of the Confucian people-oriented thought." (Jin 2008, p. 64). At the same time, Mencius pointed out the importance of the popular sentiments: "Jie and Zhou lost their throne because they lost the support of the people. They lost the support of the people because they lost their hearts. There is a way to get the throne: get the people; there is a way to get the people: get their hearts; and there is a way to get the hearts of the people: gather for the people what they desire; do not impose on them what they hate, that is all." Following Mencius, Xunzi proposed 
the famous metaphor of the boat and water: "The monarch is a boat and the people are the water. Water can carry the boat or upset it." He also believed that "Providence does not create the people for the sake of the monarch; Providence creates the monarch to let him serve his people." The greatest task of a monarch is to love and nurture his people.

When Emperor Wudi of the Han Dynasty rose to power, Confucianism became the orthodox ideology and its people-oriented thought also gained prominence. Thinkers of Han and subsequent dynasties kept interpreting them. From Jia Yi and Dong Zhongshu in the early Han dynasty to Huang Zongxi and Tang Zhen in the Ming and Qing dynasties, there were numerous thinkers and their writings were concerned with the people-oriented thought. From the development course of the people-oriented thought it is evident that it is closely linked with the monarchy. "The people-oriented thought of ancient China is an important part of the ruling thought of various dynasties. One can even say that the political principle of the Chinese monarchy is a huge carefully-constructed ideological system, with the people-oriented thought as one of the main frames" (Zhang and Zhang 2015, p. 118). On the one hand, the people-oriented thought is the most favored moral ruling tool obtained by the monarchy with the help of Confucianism that ensures the stability of the state. On the other hand, it is an ideological carrier used by Confucian officials to "soften" and "domesticate" the autocratic rule (Lin 2017). Due to this, some scholar argues that "despite the existence of autocracy and royalty in ancient Chinese politics, the popular morale was not decreased and people's livelihood was not disrupted." (Jin 2008, p. 2). Liang Qichao concludes: "A robust political ideal of China is to implement the people-oriented spirit under the rule of the monarch. Although the ideal cannot be fully realized, it has already had a deep influence on the national consciousness. So, despite the tortures by despotism, the spirit never died." (Liang 2014, p. 6). Therefore, when the monarchy was overthrown by the modern revolution, the people-oriented thought survived as the gene of civilization.

According to Philip Kuhn, the definition of China's institutional agenda is based on China's own conditions (Kuhn 2013, p. 122). Amidst the turmoil in modern China, the people-oriented tradition may be the most important binding condition for considering the country's fundamental agenda. Although the intellectual elites in modern China did not discuss the fundamental agenda of the country in a oneline fashion, focusing on "benefiting the people" to address the fundamental agenda was finally achieved (Lv 2020). During the constant collision and convergence of Chinese and Western thoughts, Marxism was finally chosen by the leaders of the social revolution, and it became the guideline for "benefiting the people." "One important reason for the rapid adoption of Marxism in China is the compatibility of socialism and traditional Chinese political thought, especially the people-oriented thought. Socialism focuses on 'society', which is in fact centered on the people; and the people-oriented thought, as the term implies, is based on the people. Both are concerned with the people and the public" (Yang 2019a, p. 7).

In fact, before Marxism became the guiding ideology of the modern Chinese revolution, the people-oriented thought and practice adopted in the country had revealed the meaning of socialism. In the Western Han dynasty, to solve the increasingly serious problems concerning people's livelihood and the economy, Emperor 
$\mathrm{Wu}$ implemented economic reforms. "Wu Ti [Emperor $\mathrm{Wu}$ ] experimented with socialism by establishing national ownership of natural resources, to prevent private individuals from 'reserving for their sole use the riches of the mountains and the sea to gain a fortune, and from putting the lower classes into subjection to themselves'. The production of salt and iron, and the manufacture and sale of fermented drinks, were made state monopolies... Great public works were undertaken to provide employment for the millions whom private industry had failed to maintain...; for a time the new system flourished ... China had never prospered so much before" (Durant 2010, p. 514). Sun Yat-sen, the forerunner of the Chinese revolution, attaches great importance to China's socialist tradition and aims to realize socialism. According to him, "China is a solid advocate of socialism, which shows that the spirit of socialism has long occupied the minds of the Chinese people. It is suitable for it to proceed as fast as it can" (Sun 2011, p. 507). "I really welcome socialism because it benefits the state and the people. It focuses on society, establishes public ownership of all things produced, and reaps benefits from them. When socialism is implemented in China, our children will have access to education and the elderly will be taken care of. Everything will run smoothly in its own place. The Republic of China will become a socialist country" (Sun 2011, p. 523). Based on the strong inertia of the people-oriented thought in ancient China, Mizoguchi Yuzo argues that modern China "was a socialist state that is peculiar to China from the beginning" (Mizoguchi 2011, p. 18).

As one of the numerous political subjects emerging after the changes took place in the late Qing dynasty, the Communist Party of China achieved the final victory partly because it inherited the classical people-oriented thought and transformed the conservative people-oriented principle into a dynamic one. This is demonstrated successively by the people-oriented principle in revolution and in development (Lv 2018). The biggest development is the birth of the mass line, which, as the main form of consultation, marks the transformation of the people-oriented thought from an idea to an institutional arrangement for state governance. People-oriented thought has finally been institutionalized. It is through the selective inheritance and creative transformation of the people-oriented principle that the Communist Party of China has opened the path of socialism with Chinese characteristics. The continuation of the political ideology and value orientation, from people-oriented principle to socialism, is embodied in the specific process of governing the country, including the distinctive consultation practice.

\subsection{The Practice Dimension of Consultative Democracy: From Consultative Institutional Arrangement to Consultative Democratic System}

"Apart from being a theoretical expression, the people-oriented thought is an institutional and a common practical expression" (Liang 2020, p. 143). Based on the value orientation of people-orientation, China has produced consultative political elements since ancient times. The Classic of Poetry (Shijing) has this line: "Ancient sages say that we should humbly ask those who mow grass and chop wood for answers," which suggests to the ruler that he should encourage freedom of speech and strike 
up a dialog with the people. To achieve effective political ruling and social governance, ancient thinkers developed a systematic approach to discussing affairs of government, which includes four aspects: encouraging the people to voice their opinions, readily listening to advice, judging after listening to all parties concerned, and embracing and coordinating different opinions while removing sameness ( $\mathrm{Wu}$ and Lu 2016, pp. 262-263). These aspects have formed formal and informal consultative institutional arrangements in the course of political practice, which are distributed at different levels of political and social life. The political tradition of consultation derived from the people-oriented thought is carried forward by the modern socialist consultative practice. It is also an important local resource for the development of contemporary China's consultative democracy. Regarding the consultative system of ancient China, this part mainly deals with the court deliberation system and the expostulation system in the central decision-making system, as well as the co-governance of officials and the gentry at the primary level (He 2013).

Court deliberation refers to a fundamental system with legal effect, under which the monarch convenes or instructs the prime minister to convene the main officials of the central government to discuss major military and political issues and make decisions accordingly. It is an important part of the central decision-making system and operating mechanism ( $\mathrm{Xu}$ and $\mathrm{Zhu}$ 1996). The system originated from the tribal councils of primitive society, which were attended by leaders of various clans to discuss and decide important matters of the tribe. "Court deliberation" emerged in as early as the Spring and Autumn Period, when the monarchs and officials of the Jin and Qin States discussed war and peace. During the Warring States Period, there were two court deliberations in the Qin State on reforming and taking down the Shu State (Sun 1993). Lin Qian organized the process of how the court deliberation system was becoming increasingly institutionalized and stylized. After the establishment of the Qin dynasty, gatherings of court officials were convened to discuss and decide on major issues, such as the emperor's title and enfeoffment. Under the rein of Emperor Wu of the Western Han dynasty, according to the nature of the issues to be discussed, participants of the court deliberation included those of the nobility who had extensive political experience and the knowledgeable scholar-officials, and their common efforts in brainstorming yielded fruitful results. During the Tang dynasty, the system of heads of the Three Departments (three top-level administrative structures) co-deciding at the political affairs hall marked a giant leap of the court deliberation system. At the time of the Song dynasty, there was a fixed place and a stylized agenda for the court deliberation, and a supervisory official in charge of it. In the early Qing dynasty, court deliberation was mainly carried out at the council of princes and ministers, whose power was significantly weakened after the establishment of the Grand Council, but the number of people involved in the deliberation remained extensive (Lin 2004, pp. 46-52). It is worth noting that as scholars paid more attention to the strengthened monarchy in the Qing dynasty, there were a lot of investigations in the Grand Council and the memorial system. However, in the late Qing dynasty, a large conference attended by the Grand Secretariats, six ministries and heads of the nine departments was often held, where the discussions were mostly related to national issues. Such consultative court deliberation, which is favorable for brainstorming and can help control public opinion, is an effective 
supplement to the monarchy and the Grand Council system in the Qing dynasty (Li 2019).

In addition to the court deliberation system, the expostulation (Jian Yi) system is another typical consultative system within the central decision-making framework. The character "Jian" has multiple connotations. Its primary meaning is "speak up to people to persuade them into doing the right thing", and its basic connotation is to enlighten others with upright words (Zhao 2000). In ancient China, "Jian Yi" meant that officials made suggestions or persuaded the monarch to prevent him from making mistakes in decision-making and correct his wrong behavior (Chao 2010). The expostulation system has a long history and scholars broadly divide its evolution in ancient China into four stages. The pre-Qin period can be regarded as the embryonic stage of the expostulation system. According to Lv Shi Chun Qiu and other documents, Emperor Yao set up the "drum for expostulation", Emperor Shun set up the "wood of slander", and Emperor Yu set up five musical instruments: bell, drum, Duo (a big bell), chime, and Tao (a small hand-drum), for subordinates to expostulate. In the Yin and Shang dynasties, full-time expostulators appeared. The Qin, Han, Wei, Jin, Southern and Northern dynasties can be regarded as the development stage of the expostulation system. Not only were there many expostulators, but also was a special organ dealing with expostulation. China's expostulation system matured in the Tang and Song dynasties, with the increasingly complete set of expostulation officials and an unprecedented rise in their power. The titles of expostulators, such as "Shi Yi" and "Bu Que", in the Tang dynasty meant that they were responsible for reminding the monarch and correcting the monarch's behavior. In the Song dynasty, offering expostulation and discussing affairs of government became so popular that it even turned out that the emperor and the scholar-officials ruled the state together. In the Yuan, Ming, and Qing dynasties, full-time expostulators ceased to exist and their functions were merged into the supervisory system, hence "the integration of supervision and expostulation" (Chao 2015).

In addition to the court deliberation system and the expostulation system of the central decision-making framework, the co-governance of officials and the gentry at the primary level also shows an obvious attribute of consultation. Faced with such an enormous society, traditional China adopted a bureaucracy to administer it. During the development of the bureaucracy, changes in the rules of selection of officials made it less hereditary and aristocratic. In particular, the implementation of the Imperial Examination system caused the bureaucracy to become more civilian and specialized, hence the emergence of the gentry (Sun 1992). The authority of the gentry mainly came from two sources: one is the orthodox Confucianism, and the other is the cultural network and social knowledge of the rural areas. On the one hand, the gentry and local officials who had been significantly influenced by Confucian classics for a long time shared the same set of value systems, and the two resonated conceptually. On the other hand, compared to local officials who were employed cross-domain posts and administered a vast area for a short term, the gentry knew more about the local customs and residents, and it was easier for them to deal with local problems. Therefore, they naturally became a force that local officials relied upon. The gentry acted as an intermediary and bond between local officials and the people by virtue of two sources of authority: one is that they shared 
values with officials and conveyed the will of the state to the people; the other is that they shared the cultural network and social knowledge with the people and conveyed the needs of the people to local officials. It is precisely based on these two elements that the gentry became "the only group that could legitimately represent the local community in discussing local affairs with the officials and in participating in the governing process" (Qu 2003, p. 283).

In the process of primary-level governance, the gentry assumed many public functions, such as mediating disputes, developing education, and maintaining public order. These informal behavior with a public attribute provided sufficient stability and flexibility for local governance in various parts of China. By contrast, without the cooperation of the gentry, it would be difficult for local officials to effectively govern the people within their jurisdiction. "Actually, the emperor's appointee to any magistracy could administer it only with the cooperation of the gentry in that area" (Fairbank 1999, p. 38).

The court deliberation system and the expostulation system were formal consultative systems in ancient China. However, as mentioned above, the people-oriented thought is accompanied by monarchial politics, and the consultative system based on the people-oriented thought is inevitably dominated by monarchial power. Although they played an important role in restricting the arbitrariness of decision-making and implementing the value of people-orientation, in general, the court deliberation system mainly provided suggestions and reference, while the expostulation system mostly served as a reminder and remedy for the behavior of the monarch. Therefore, "the consultation [embodied by the two] was often just a decision-making counseling conducted under the leadership of the monarch" (Chen 2006, p. 88). As an informal consultative system in primary-level governance, co-governance of officials and the gentry was based on the existence of gentry power, which was an extension of imperial power to some extent. Therefore, primary-level consultation was in a way monarchial as well.

When Marxism became the guiding ideology of the Chinese revolution, the Communist Party of China (CPC) established the mass line revolving around "the people" while eliminating the dominance of the monarchy. As Mao Zedong said, "The line of the Communist Party of China is the mass line" (Party Literature Research Center, CPC Central Committee 1993, p. 409). On the one hand, the masses are the source where the CPC gains its strength. "For the revolutionary war is a war of the masses; it can be waged only by mobilizing the masses and relying on them" (Mao 1991a, p. 136). Therefore, the support of the masses guarantees the success of the revolution. "If we want to win, we must do a great deal more. We must lead the peasant's struggle for land and distribute the land to them, heighten their labor enthusiasm and increase agricultural production, safeguard the interests of the workers, establish cooperatives, develop trade with outside areas, and solve the problems facing the masses - food, shelter and clothing, fuel, rice, cooking oil and salt, sickness and hygiene, and marriage. In short, all the practical problems in the masses' everyday life should claim our attention" (Mao 1991a, pp. 136-137). On the other hand, the masses are the source where the CPC gains its wisdom. "It has to be understood that masses are the real heroes, while we ourselves are often childish and ignorant, and without this understanding it 
is impossible to acquire even the most rudimentary knowledge" (Mao 1991b, p. 790). Repeated communication and consultation with the masses is the prerequisite for scientific decision-making. "In all the practical work of our Party, all correct leadership is necessarily "from the masses, to the masses". This means: take the ideas of the masses (scattered and unsystematic ideas) and concentrate them (through study turn them into concentrated and systematic ideas), then go to the masses and propagate and explain these ideas until the masses embrace them as their own, hold fast to them and translate them into action, and test the correctness of these ideas in such action. Then once again concentrate ideas from the masses and once again go to the masses so that the ideas are persevered in and carried through. And so on, over and over again in an endless spiral, with the ideas becoming more correct, more vital and richer each time. Such is the Marxist theory of knowledge" (Mao 1991b, p. 899).

Under the guidance of the mass line with the people at its core, China has created a wealth of consultation practices in different historical periods of revolution and construction. Before the founding of the PRC, the representative forms of consultative political organizations included the "three one-third system" (the CPC accounted for one-third, the leftist progressives accounted for one-third, and the centrists accounted for one-third) during the War of Resistance Against Japanese Aggression and the People's Political Consultative Conference on the eve of the founding of the PRC. In fact, the two are in the same line, and both reflect the democratic operation of full discussion and consultation. From the founding of the PRC to the new era, China formed an extensive and multi-layered consultative democracy system. "Consultative democracy has been integrated into the whole process of Chinese socialist democracy" (Xi 2017, p. 294). Consultative politics is not only the foundation for the consolidation of China's state system, but also the key to the improvement of China's political system. The principle of consultation is contained in both the fundamental political system and the basic political system of China (Lin 2007). In the policy process, the consultative consensus-based pattern of democracy runs through the central government's decision-making, departmental decision-making, and local government's decision-making (Yang 2018, pp. 368-409). In addition to political consultation and government consultation, the steady advancement of social consultation and citizen consultation will also expand the practice space of the consultative democratic system. Therefore, China's consultative democracy is an inherited and creative pattern of democracy, and it is in an unfinished stage of development.

\section{Popular Sovereignty and the Value Pattern and Practice Pattern of Democracy}

"Popular sovereignty" as a modern overall value is indisputable, but the implementation of popular sovereignty requires not only a practice mechanism, i.e., the practice pattern mentioned in this paper, but also a civilization system that the practice pattern relies on to produce and survive, i.e., the value pattern mentioned in this paper. "Popular sovereignty" transcends the civilization system and becomes the 
overall common value of mankind. Both, the value pattern, which rests on the civilization system, and the practice pattern produced in the value pattern, are required to realize this common value. The diversity of civilization means the diversity of the value pattern of democracy, which means the diversity of the practice pattern of democracy as the value pattern produces the practice pattern. This is a basic fact offered to us by the history and reality of Western civilization generating party democracy and Chinese civilization generating consultative democracy. The Chinese civilization is known for its stability and continuity, and the consultative politics and consultative democracy born on this fertile land also bring out the best in it. By contrast, the party democracy, i.e., liberal democracy, born in Western civilization confuses the value pattern and practice pattern of democracy, and is promoted as the sole pattern of democracy. We believe that major changes in Western civilization have resulted in serious tensions between the practice pattern and the value pattern of party democracy, not to mention the relationship between party democracy and other value patterns.

Liberal democracy is facing severe challenges within Western civilization, among which the rise of identity politics is the trickiest. Historically, identity politics has played a significant role in remedying political and cultural inequalities, but this political force, which is a combination of political thought and political movement, has increasingly turned into a source of new inequalities and social divisions. Identity politics has triggered a crisis in liberal democracy, but in fact the latter intensified the negative tendency of the former. Party democracy has become an intermediary for identity politics to trigger political conflicts, making identity politics more unequal and aggressive. In view of the critical position of ethnic identity in political reality, when strengthening the basics of voters, party politics will solidify an ethnic group into supporters of a certain party. Party politics is therefore "identitypoliticized" or "tribalized", meaning that the affiliation of a party is no longer based on the balance of issues, policies, and interests, but is entirely out of the identity of certain social attributes. That will lead to a more solidified, fierce, and unreconcilable political polarization and make it difficult to build a clear consensus on national development (Diao 2020). Identity politics and vicious partisanship have "distorted liberalism's message and prevented it from becoming a unifying force capable of governing" (Lilla 2018, p. 3). In this sense, the challenges faced by liberal democracy will threaten the foundation of Western civilization. More importantly, the "election-oriented" party politics mixes cultural conflicts with ethnic disputes for political hype, trying to use cultural issues to conceal or divert the more fundamental economic and social inequalities (Wei 2021).

Liberal democracy and party democracy represent the value pattern and the practice pattern of Western democracy, respectively, and they are the equivalents of Western civilization in terms of ideas and systems. From the perspective of Western political history, the Western civilization that was born in the Middle Ages has brought about an equal and tolerant political identity, forming a homogeneous foundation for political development. Secularism or liberalism, derived from the Christian tradition, has its own unique moral connotations. It is not a neutral or "valuefree" framework (Siedentop 2021, pp. 416-417). Therefore, to confront the crisis 
of liberal democracy, the way forward for the Western world is to reconsolidate its civilized subjectivity and reshape the common belief in the state and liberalism.

In contrast, the power and influence of liberal democracy are based on Western civilization. When liberal democracy becomes a universal force and spreads to other civilized areas, it can hardly maintain political order and becomes a pure means of competition for power. This shows "how insensitive Western democracies have been to the need to develop models and styles of democracy which are likely to take and find acceptance in non-Western cultures." (Arblaster 2005, pp. 153-154). As Marx says: "Men make their own history, but they do not make it as they please; they do not make it under self-selected circumstances, but under circumstances existing already, given and transmitted from the past" (Central Compilation and Translation Bureau 2012, p. 669). There is no rigid model for the realization of democratic politics. Its flexible form and lasting power are included in the historical context of different civilizations. " ... those who try to define democracy only in terms of presentday realities - as a type of political system or culture which some societies possess and others do not-will find themselves left behind by history." (Arblaster 2005, p. 9).

The fate of party democracy in Islamic civilization is thought-provoking. Many people expected the political transition in the Islamic world to be what is called the "Arab Spring", but it turned out to be the "Arab Winter". The underlying mechanism is obviously a violent collision between the practice pattern and the value pattern of democracy. The Islamic civilization gave birth to unique democratic elements. The principles of "consultation", "public deliberation", and "institution formulation" mentioned in the Koran can be seen as important forms of early democratic practice for the Islamic world (Ma 2000; Wang 2007a, b; Keane 2016, p. 120). Therefore, the Islamic world has its own democratic traditions. But the United States of America has attempted to graft the party democracy centered on competitive elections to the Islamic civilization. It is greatly different from Western civilization; the "Greater Middle East Democracy Initiative" and the "Arab Spring" have resulted in cruel competition and bloodshed between sects and ethnic groups (Yang 2021, pp. 232-240). What will be difficult but worth looking forward to is that Islamic democracy may move forward with a view to reinterpreting and applying the principles and historical practices of equality and democracy advocated by traditional religious beliefs.

Except for the Islamic states, the third wave of democracy has made liberal democracy gain unprecedented influence across the world, being emulated in many non-Western countries. Although specific election and representative systems seem to be accepted in some countries, they have become institutional tools for creating problems rather than solving them. Many Third World countries have not yet achieved a stable national identity and their politics is based on tribes. As a result, competitive elections have become political struggles between different religions, races, or classes (viz. the rich vs. the poor), which ultimately lead to national division or periodic political turmoil and poor governance (Yang 2014a, p. 26).

The approach of historical political science can offer a fuller understanding of the patterns of democracy as a continuum of the civilization system. On the one hand, democracy carries the meaning of history, and we should follow the principle of 
long-term historical analysis to understand and judge its evolutionary trajectory in a holistic and continuous manner rather than a fragmented one (Yang and Shi 2020). On the other hand, democracy carries the meaning of civilization, and different patterns of democracy have their own civilization roots. It is difficult to completely surpass the civilization attributes on which it depends. As a continuum of a specific civilization, it can hardly be grafted onto a different civilization. Therefore, instead of emphasizing the "universality" of a certain pattern of democracy, it is better to pay attention to the "suitability" of different patterns of democracy. This also shows respect for the diversity of world civilizations. If the crisis of liberal democracy in the West is an abnormal state caused by changes in economic and social conditions, the crisis of liberal democracy in the non-Western world is a normal state caused by the "translational effect" of the patterns of democracy. For developing countries, liberal democracy in favor of competitive elections may lead to further consolidation and opposition of decentralized power within the country. Ultimately, the consequences of poor governance will only be borne by the people of these countries.

This paper does not exhaustively list and restore every single detail of how the value pattern and the practice pattern of democracy are formed in each civilization but outlines the overall picture and historical context derived from the patterns of democracy in different civilizations. Therefore, the research may have omitted certain details and even seem fragmented and disorderly, but it avoids dismissal of the civilized connotations of democracy with a fragmented historical perspective. The Western Christian civilization and plural political rule tradition have derived liberal democracy as a value pattern, which runs in practice in the pattern of party democracy. The governing practice of "great unification" in Chinese civilization gave birth to people-oriented democracy as a value pattern, which is manifested as consultative politics in political practice and has been transformed into socialist democracy and consultative democracy since modern times. The patterns of democracy have their own long-evolved civilization bases, and both, the value pattern and the practice pattern, originate from a specific history. The practice pattern of democracy is valid only if it is compatible with the specific value pattern. The experience of democratic politics can serve as a reference for one another only by acknowledging the diversity of the patterns of democracy. The analytical framework of the value pattern and the practice pattern of democracy, together with the "homogeneous conditions of democracy" (Yang 2014b), is theoretically separated from the general "patterns of democracy" in the West, pointing to the reasons for the predicament of liberal democracy and the rationality of other patterns of democracy.

Funding This paper is supported by the Outstanding Innovative Talents Cultivation Funded Programs 2020 of Renmin University of China.

\section{Declarations}

Conflict of interest I declare that I have no conflict of interest in any way in this paper.

Open Access This article is licensed under a Creative Commons Attribution 4.0 International License, which permits use, sharing, adaptation, distribution and reproduction in any medium or format, as long as you give appropriate credit to the original author(s) and the source, provide a link to the Creative 
Commons licence, and indicate if changes were made. The images or other third party material in this article are included in the article's Creative Commons licence, unless indicated otherwise in a credit line to the material. If material is not included in the article's Creative Commons licence and your intended use is not permitted by statutory regulation or exceeds the permitted use, you will need to obtain permission directly from the copyright holder. To view a copy of this licence, visit http://creativecommons.org/ licenses/by/4.0/.

\section{References}

Arblaster, Anthony. 2005. Democracy. Trans. Sun Rongfei et al. Jilin People's Press.

Bennett, Judith M., and C. Warren Hollister. 2007. Medieval Europe: a short history. Trans. N. Yang and Y. Li Yun. Shanghai Academy of Social Sciences Press.

Berman, Harold J. 2008. Law and revolution: the formation of the western legal tradition. Trans. W. He et al. China: Law Press.

Braudel, Fernand. 2017. A history of civilizations. Trans. S. Chang et al. China CITIC Press.

Capoccia, Giovanni, and Daniel Ziblatt. 2010. The historical turn in democratization studies: a new research agenda for europe and beyond. Comparative Political Studies 43 (8/9): 931-968.

Cartledge, Paul. 2016. Ancient Greek political thought in practice. Trans. L. Tao. Huaxia Publishing House.

Central Compilation and Translation Bureau (eds.). 2012. Marx \& Engels Collected Works (Volume 1). People's Publishing House.

Chao, Zhongchen. 2010. On the expostulation thought and expostulation system in Ancient China. Dongyue Tribune 9: 63-67.

Chao, Zhongchen (eds.). 2015. The history of the expostulation system in China. Zhonghua Book Company.

Chen, Binghui. 2016. Consultative democracy from the perspective of the complexity of national governance. Social Sciences in China 5: 136-153.

Chen, Shengyong. 2006. Consultative political tradition and local democratic development of China, In The Development of Consultative Democracy: Proceedings of the International Symposium on Consultative Democracy and Local Democracy in China, eds. Chen Shengyong and He Baogang. China Social Sciences Press.

Collier, Ruth Berins. 1999. Paths toward democracy: the working class and elites in Western Europe and South America. Cambridge: Cambridge University Press.

Cong, Riyun. 2003. Between God and Caesar: Christian Dualism and Modern Liberalism. SDX Joint Publishing Company.

Coulanges, Numa Denis Fustel de. 2005. The Ancient City: A Study of the Religion, Laws, and Institutions of Greece and Rome. Trans. L. Tan et al. East China Normal University Press.

Dahl, Robert A. 2006. Democracy and its critics. Trans. H. Cao, D. Tong. Jilin People's Press.

Dahl, Robert, and Ian Shapiro. 2020. On democracy. Trans. F. Li. China Renmin University Press.

Diao, Daming. 2020. Identity Politics, "Tribalization" of Partisanship and the 2020 U.S. Election. Foreign Affairs Review 6: 48-73.

Dunn, John. 2011. Democracy: the unfinished journey, 508 BC to AD 1993. Trans. M. Lin et al. Jilin People's Press.

Durant, Will. 2010. The story of civilization: our oriental heritage. Trans. Taiwan Youth Cultural. Huaxia Publishing House.

Eisenstadt, S.N. 2006. Reflections on modernity. Trans. X. Kuang, A. Wang. SDX Joint Publishing Company.

Fairbank, John King. 1999. The United States and China. Trans. L. Zhang. World Affairs Press.

Finley, Moses I. 2016a. Politics in the ancient world. Trans. S. Yan, Z. Huang. The Commercial Press.

Finley, Moses I. 2016b. Democracy ancient and modern. Trans. X. Guo, Z. Guo. The Commercial Press.

Goff, Jacques le. 2011. Medieval civilization: 400-1500 A.D. Trans. J. Xu. Truth \& Wisdom Press.

Hansen, Mogens Herman. 2014. The Athenian Democracy in the age of demosthenes: structure, principles and ideology. Trans. S. He, X. Ouyang Xudong. East China Normal University Press.

He, Baogang. 2013. Confucian consultation: the source and flow of authoritarian consultation in China. Journal of the History of Political Thought 4: 1-21. 
He, Jiacheng. 2020. The turn and enlightenment of the research on democracy theory. Academic Monthly 11: 87-94.

Held, David. 1998. Models of democracy. Trans. J. Yan et al. Central Compilation \& Translation Press.

Huang, Yang. 2002. The 2500th Anniversary of the Birth of Democratic Politics? - Research on Contemporary Athenian Democratic Politics. Historical Research 6: 123-130.

Huntington, Samuel. 2010. The clash of civilizations and the remaking of world order. Trans. Q. Zhou et al. Xinhua Publishing House.

Jin, Yaoji. 2008. History of Chinese people-oriented thought. China: Law Press.

Keane, John. 2016. The life and death of democracy. Trans. W. An. Central Compilation \& Translation Press.

Knutsen, Carl Henrik, Jørgen. Møller, and Svend-Erik. Skaaning. 2016. Going historical: measuring democraticness before the age of mass democracy. International Political Science Review 37 (5): 679-689.

Kuhn, Philip. 2013. Origins of the Modern Chinese State. Trans. J. Chen, Z. Chen. SDX Joint Publishing Company.

Li, Wenjie. 2019. Court deliberation and decision-making: The Conference of Grand Secretariats and Heads of Six Ministries and Nine Departments in the Late Qing Dynasty. Historical Review 3: 100-116.

Liang, Qichao. 2014. History of political thought in the Pre-Qin period. Shanghai Classics Publishing House.

Liang, Zhiping. 2020. On politics: the idea of state governance in ancient China. SDX Joint Publishing Company.

Lijphart, Arend. 2006. Patterns of democracy: government forms and performance in thirty-six countries. Trans. Q. Chen. Peking University Press.

Lilla, Mark. 2018. The End of Identity Liberalism. The Reflection of Western Political Correctness. Jiangsu People's Publishing LTD.

Lin, Hong. 2017. The historical logic of the people-oriented thought and its modern value. Journal of Renmin University of China 3: 90-98.

Lin, Qian. 2004. Power and law in Ancient China. China University of Political Science and Law Press.

Lin, Shangli. 2003. Consultative politics: a reflection on the development of democratic politics in China. Academic Monthly 4: 19-25.

Lin, Shangli. 2007. Consultative politics: the basic form of democratic politics with Chinese characteristics. Studies on Mao Zedong and Deng Xiaoping Theories 9: 17-26.

Lipset, Seymour Martin. 2011. Consensus and conflict: essays in political sociology. Trans. H. Zhang et al. Shanghai People's Publishing House.

Lv, Xiaobo. 2018. From defensive to active: the transition of the communist party of China and the people-oriented principle. Jilin University Journal Social Sciences Edition 1: 5-23.

Lv, Xiaobo. 2020. How to benefit the people: the continuation and creation of the "fundamental agenda" of the modern state: a discussion centered on Wang Tao, Li Dazhao and Mao Zedong. Journal of Literature, History \& Philosophy 2: 5-20.

Ma, Mingxian. 2000. Exploration of Islamic democratic consultation System. Journal of Lanzhou University (Social Sciences) 1: 116-120.

Macpherson, C. B. 2018. The Life and times of liberal democracy. Trans. F. Yan. Jiangsu People's Publishing, LTD.

Mao, Zedong. 1991a. Selected Works of Mao Zedong (Vol. 1). People's Publishing House.

Mao, Zedong. 1991b. Selected Works of Mao Zedong (Vol. 3). People's Publishing House.

McClelland, J. S. 2014. A History of Western Political Thought. Trans. H. Peng. China CITIC Press.

Mizoguchi, Yuzo. 1996. China Studies from the Japanese Perspective. Trans. S. Li et al. China Renmin University Press.

Mizoguchi, Yuzo. 2011. China as Method. Trans. J. Sun. SDX Joint Publishing Company.

Møller, Jørgen. 2015. The medieval roots of democracy. Journal of Democracy 26 (3): 110-123.

Moore, Barrington. 2012. Social origins of dictatorship and democracy: lord and peasant in the making of the modern world. Trans. Z. Wang, J. Gu. Shanghai Translation Publishing House.

Ning, Zhenjiang. 2019. The people-oriented thought in ancient China and Limited Kingship in Shang and Zhou Dynasties. The Journal of Humanities 1: 25-33.

Ober, Josiah. 1989. Mass and elite in democratic Athens: rhetoric, ideology, and the power of the people. Princeton: Princeton University Press. 
Schmitter, Philippe. 2012. Twenty Five Years, Fifteen Findings. In Guillermo O’Donnell and Philippe Schmitter (eds.) Transitions from Authoritarian Rule: Tentative Conclusions about Uncertain Democracies (pp. 106-107). Trans. W. Jing, S. Chai. New Star Press.

Party Literature Research Center, CPC Central Committee (eds.). 1993. Mao Zedong Collected Works (Vol. 2). People's Publishing House.

Qu, Tongzu. 2003. Local government in China under the Qing. Trans. Z. Fan, F. Yan. China: Law Press.

Rowe, Christopher, and Malcolm Schofield (Eds.). 2016. The Cambridge History of Greek and Roman Political Thought. Trans. S. Yan. The Commercial Press.

Rueschemeyer, Dietrich, Evelyne Huber Stephens, and John D. Stephens. 2016. Capitalist development and democracy. Trans. Q. Fang. Fudan University Press.

Sartori, Giovanni. 2009. The theory of democracy revisited. Trans. K. Feng, K. Yan. Shanghai People's Publishing House.

Schumpeter, Joseph. 1999. Capitalism, socialism and democracy. Trans. L. Wu. The Commercial Press.

Shi, Qipeng. 2019. The methodological basis of historical political science. Chinese Political Science 2: 70-98.

Siedentop, Larry. 2021. Inventing the Individual: the origins of western liberalism. Trans. Q. He. Guangxi Normal University Press.

Stasavage, David. 2016. Representation and consent: why they arose in Europe and not elsewhere. Annual Review of Political Science 19: 145-162.

Sun, Jiazhou. 1993. Remarks on the court deliberation system. Social Science Front 3: 163-164.

Sun, Liping. 1992. The growth and decline of the power of the nobility and gentry in the traditional Chinese society and its influence on the social structure. Tianjin Social Sciences 4: 58-64.

Sun, Yat-sen. 2011. The Complete Works of Sun Yat-sen (Vol. 2). Zhonghua Book Company.

Tierney, Brian, and Sidney Painter. 2011. Western Europe in the Middle Ages, 300-1745. Trans. C. Yuan. Peking University Press.

Tilly, Charles. 2008. Contention and Democracy in Europe, 1650-2000. Trans. Z. Chen et al. Truth \& Wisdom Press.

Wallace, Robert W. 2006. Law and Rhetoric: Community Justice in Athenian Courts, In A Companion to the Classical Greek World, ed. Konrad H. Kinzled. Malden: Blackwell Publishing Ltd.

Wang, Bo. 2007a. Comparison of democratic values contained in Islamic and Western Civilizations. Arab World Studies 2: 60-67.

Wang, Yixin. 2007b. Heroes and democracy: an analysis of democratic politics in Ancient Athens. World History 4: 4-13.

Watkins, Frederick. 2016. The political tradition of the west: a study in the development of modern liberalism. Trans. F. Li. Guangxi Normal University Press.

Wei, Nanzhi. 2021. Cultural identity conflicts and social inequalities in the U.S.: the cultural and social origins of racial contradictions. Academic Monthly 2: 85-96.

Wells, H. G. 1982. The outline of history: being a plain history of life and mankind. Trans. W. Wu et al. People's Publishing House.

Wiarda, Howard (eds.). 2004. Comparative democracy and democratization. Trans. Y. Rong. Peking University Press.

Wood, Ellen Meiksins (eds.). 2007. Democracy against capitalism: renewing historical materialism. Trans. W. Lv et al. Chongqing Publishing House.

Wood, Ellen Meiksins. 2019a. Citizens to lords: a social history of western political thought from antiquity to the late middle ages. Trans. S. Cao: Yilin Press.

Wood, Ellen Meiksins. 2019b. Liberty and property: a social history of western political thought from renaissance to enlightenment. Trans. S. Cao: Yilin Press.

Wu, Qian, and Lu Xing. 2016. On the ideas of political consultation in ancient China. Journal of Tianjin Normal University (Social Science) 4: 13-20.

Xi, Jinping. 2014. The governance of China. Foreign Languages Press.

Xi, Jinping. 2017. The governance of China (Volume 2). Foreign Languages Press.

$\mathrm{Xu}$, Lianda, and Ziyan Zhu. 1996. The emperor system of China. Guangdong Education Publishing House.

$\mathrm{Xu}$, Yong. 2016. The Chinese path from the perspective of historical continuity. Social Sciences in China 7: 4-25.

Yang, Guangbin. 2014a. Review of comparative politics (Vol. 3). China Social Sciences Press.

Yang, Guangbin. 2014b. The falsification of several popular theoretical propositions of democratization. Beijing Daily Mar. 17. 
Yang, Guangbin. 2016a. The theory of the community of Chinese civilization genes: an epistemology to understand the future of China. People's Tribune 15: 58-61.

Yang, Guangbin. 2016b. The abuse and restatement of the concept of legitimacy. CASS Journal of Political Science 2: 2-19.

Yang, Guangbin. 2018. Chinese political epistemology. China Social Sciences Press.

Yang, Guangbin. 2019a. Contemporary political development in China from the perspective of historical political science. CASS Journal of Political Science 5: 2-14.

Yang, Guangbin. 2019b. What is historical political science? Chinese Political Science 2: 3-21.

Yang, Guangbin, and Qipeng Shi. 2020. An Analysis of the functions of historical political science. CASS Journal of Political Science 1: 10-20.

Yang, Guangbin. 2021. World political theory. China Social Sciences Press.

Zhang, Fentian. 2007. On the theory of political adjustment in ancient China: the core position of the people-oriented thought in ancient Chinese political theories. Tianjin Social Sciences 2: 120-126.

Zhang, Fentian, and Hong Zhang. 2015. On the connotation and denotation of the people-oriented thought in ancient China. Journal of Northwest University (philosophy and Social Sciences Edition) 1: 113-118.

Zhang, Hao. 2010. Dark consciousness and democratic tradition. New Star Press.

Zhang, Xiuxia. 2015. Research on consultative democracy in the process of Chinese democracy. Central Compilation \& Translation Press.

Zhao, Yingcheng. 2000. A study of the expostulators in ancient China. Journal of Peking University (Philosophy and Social Sciences) 3: 97-104.

Ziblatt, Daniel. 2006. How did Europe democratize? World Politics 58 (2): 311-338.

Jiacheng He Ph.D. candidate of School of International Studies, Renmin University of China. His areas of study include democratic theory, democratization, institutional change and comparative historical analysis. 